\title{
POLITICAL CLIENTELISM AS THE WAY OF SURVIVAL OF RADICAL ISLAMIC GROUP MOVEMENT IN CIANJUR, WEST JAVA
}

\author{
NUR KAFID ${ }^{1}$ \\ Institut Agama Islam Negeri Surakarta
}

\section{Abstract}

This study aims to analyze the existence and orientation shift of the radical Islamic group movement in the era of democratic decentralization, with the case study of Islamic Reformist Movement in Cianjur, West Java, therewith influencing factors. Based on the qualitative method, the data collected from various sources reveal that there is an orientation shift of radical Islamic group movement in the era of democratic decentralization; from 'Islamism' to 'premanism'. 'Islamism', that usually becomes the main issue, has now shifted to the domination of economic resources. This orientation shift is one of the ways for its survival. Patron-client political model of the New Order regime appears but in different forms; its characteristics and forms are also more fluid. Before and during the beginning of the Reformation Era, the orientation of radical Islamic group movement is more dominated by ideological motive such as the implementation of Islamic sharia, while during the era of democratic decentralization, its movement orientation shifts to economic pragmatism.

Studi ini bertujuan untuk menganalisis eksistensi dan pergeseran orientasi gerakan kelompok Islam radikal di era desentralisasi demokrasi, dengan studi kasus Gerakan Reformis Islam di Cianjur, Jawa Barat, serta faktor-faktor yang memengarubinya. Dengan metode kualitatif, data yang di-

Corresponding author; email: ${ }^{1}$ mashafid@gmail.com.

ISSN 0852-7172 (p) 2461-064X (e)

(C) 2018 Walisongo: Jurnal Penelitian Sosial Keagamaan

http://journal.walisongo.ac.id/index.php/walisongo 
kumpulkan dari berbagai sumber mengungkapkan bahwa ada pergeseran orientasi gerakan kelompok Islam radikal di era desentralisasi demokrasi; dari 'Islamisme ke 'premanisme'. 'Islamisme' yang pada awalnya menjadi isu utama gerakan, telah bergeser ke arah penguasaan sumber daya ekonomi. Pergeseran orientasi ini merupakan menjadi salah satu kunci kelangsungannya. Model politik patron-klien ala rezim Orde Baru kembali muncul meski dengan bentuk yang berbeda; sifat dan bentuknya lebih cair. Jika sebelum dan pada periode awal reformasi orientasi gerakan ormas keagamaan radikal lebih didominasi motif ideologis: penegakan syariat Islam, di era desentralisasi demokrasi ini orientasi gerakannya bergeser ke arah pragmatisme-ekonomis.

Keywords: clientelism; democratic decentralization; patron-client; premanism; radicalism.

\section{Introduction}

Procedurally and substantially, the process of democratization in Indonesia is continuously increasing. It can be seen from the implementation of direct General Election (Pemilu) and Local Election (Pemilukada) that strengthens the state-citizen relations, and the citizen awareness to the freedom of expression. This condition also brought changes to the character and life of the Indonesian society whether socially, politically, economically, or religiously. And for almost two decades, various religious expressions have been more dominating all those dimensions of life.

The domination of religion in the various dimensions of life in Indonesia is surely acceptable. But the pattern of religion and state relations in Indonesia at that time is unclear (Iqbal 2014; Nurcholish 2011), especially during the New Order Era (Mudhoffir 2015), even up to now religion always appears as a 'shield', 'wrap', even a 'mask' for the social, economic, and polit- 
ical benefit (Human Right Watch 2013; Rizky and Umar 2010) by certain individual or group (Kafid 2016). This condition continues even tends to increase after the fall of the New Order Regime in 1998 up to the present (Jati 2013). Ironically, in some cases, there are individuals or groups that frequently employ the ways of violence for the purpose of religious interest or ethnicity, and they have freedom in applying violence (Mubarak 2015).

Freedom of expression for every citizen is fully guaranteed by the law in a country that applies democratic system, such as in Indonesia. But, unfortunately it has been utilized by individuals/groups of violence perpetrators to act in response to various problems in the society including the Islamic groups that actively carry the issue of khilafah at the national level and the implementation of Islamic sharia in the local level (Buehler and Muhtada 2016), mass mobilization, and even economic zone control (Kafid 2016). These phenomena are almost similar to the practice of bossism in Philippines and Thailand, wherein the groups that apply violence have dominant role in the process of power contestation and economic resources control at the local level (Sidel 1996).

As the democratic decentralization policy in Indonesia is strengthening, the phenomena of violence with religious reason and ethnic also have moved to the local domain, although such case also emerges at the national level. In Jakarta, a model of 'premanism' is seen in Betawi's Youth Communication Forum (Forkabi) and Betawi Rempug Forum (FBR). In Madura, after the construction of the Suramadu bridge, new middle classes emerged with patron political practices where they successfully monopolize economic resources by using religion as a means to perpetuate their political interests (Haliq 2014). In West-Kalimantan, the utilization of ethnic and religious identity is also dominant in the process of politics and security. Dayak Tradi- 
tional Council (MAD) involved in the process of mass mobilization and political support during the election process of the regional head (governor) (Jumadi and Yakoop 2014). In Buleleng, Bali, politics based on ethnic and religious identity also has a big role in various actions of political violence, economic domination, and premanism (Suputra et al. 2011). While in Solo, Central Java, the Islamic Youth Front of Surakarta (FPIS), a radical group that initially campaigned for the implementation of Islamic Sharia and liked committing raids on discotheque, then changed its movement into a motive of economy and politics (Kafid 2016).

There are many studies elaborating the analysis on the model of premanism and patron-client political model but typically limited to the cases of the secular groups and/or secular political parties. Here, the purpose of the study is to investigate the existence and orientation shift of the radical Islamic group movement in the era of democratic decentralization along with its influencing factors, with a case study of Islamic Reformist Movement (Garis) in Cianjur, West Java.

Then, in addition to the necessary to guaranty the freedom of expression and the proper process of decentralization in the nation-state context, it also needs to see how exactly the existence and orientation of radical Islamic group in the local level are. Therefore, it is necessary to conduct a deeper and comprehensive study of the existence and orientation shift of the radical Islamic group movement in the era of democratic decentralization along with its influencing factors. The writer believes that the output of this study can give contribution to the scope of the institution, especially in the development process of democratization at the local level of Cianjur, and throughout Indonesia in general. The result of the study also can be used as a material reference in formulating the policy, especially related to the implementation of democracy. 
Similar to Solo, in Cianjur, West Java, there is a radical Islamic group named the Islamic Reform Movement (Garis). The group was formed in 1998, initially became an element of support for the implementation of Islamic Sharia in West Java. But as time goes by, Garis has changed its movement into a kind of 'gangster' whose activities are similar to the local groups of 'premanism', such as Pemuda Pancasila, Pemuda Siliwangi, and Gibas. Garis extends its influence from religious issues to the occupancy of areas. It includes "securing" the market, controlling parking at strategic locations, and being 'backing' for people who have problems with leasing (debt-collector) (Poskotanews 2012; Budiyanto 2012). In addition, Garis also has a network with Muslim politicians and state apparatuses, and now becomes one of the important actors in the control of the economy in the local area of Cianjur.

Historically, in the past, West Java, particularly Garut, Tasikmalaya, Ciamis, and Cianjur have become the basis of struggle to seize power and to establish Islamic State through Darul Islam Movement where Kartosuwiryo once built armed forces and trained the youths (Tempo 2010). In fact, based on the monitoring result on religious freedom conducted by Setara Institute (Hasani and Naipospos 2010), It is found that some areas in West Java always place on the first ranks with the highest number of violence A number of pesantrens in West Java allegedly become the potential basis for the growth of violence movement. Jamaah Islamiyah (JI) is also noted to have established a pesantren as one of its basis for the flourish of its political ideology in this region.

Various radical Islamic group movements in West Java, according to Setara Institute (Hasani and Naipospos 2010) have four various forms, depending on the agenda they carry during the action such as the enforcement of Islamic sharia, eradication 
of immorality and the sects considered heretical, and anti-apostasy movement. In committing their actions, they build political support from politicians and local elites, especially when there are important political moments, like General Election or Local Election. For example, in 2001, the local political situation in Cianjur Regency greatly benefited Islamic organizations, such as Garis. At that time, Wasidi Swastomo was elected as the new Cianjur Regent. Wasidi initiated the implementation of Islamic sharia through moral improvement, known as the Community Development Movement of Akhlakul Karimah (Gerbang Marhamah). This movement is used by some local political elites as a political campaign tool to get support from various Islamic organizations/groups, including Garis.

Various acts of terror and violence committed by Garis and any other similar groups, in Cianjur, if not taken into account could be serious threat, both for supremacy of law and legislation, as well as for the democratization process in Indonesia in general. Such group will always reemerge and even flourish in line with the strengthening of democratic decentralization policy. Why is the movement of the radical group like Garis able to survive, even more influential in line with the process of democratization in Indonesia? Why did Garis which was at the beginning of its foundation carry the religious (Islamic) ideology, then transformed to a kind of 'gangster' and able to control the economic zone? Those are the urgency of this study.

In this study, the writer uses a qualitative approach to reveal social reality and obtain comprehensive data related to the existence and orientation of radical Islamic group movement in the era of democratic decentralization, with the case study of Garis in Cianjur, West Java. In-depth interview of 12 key informants from local media, local politicians (from Islamic and secular-based political parties), business actors, academicians, 
pesantren, religious organizations and other non-religious mass organizations were conducted to obtain the primary data. They are the parties who know enough about Garis, even have relations with the activities of Garis. In addition, to sharpen the analysis, the writer also conducted library research from various sources such as books, magazines, newspapers, and other sources related to the subject matter of this research. From the data collected then they are analyzed through the steps of studying the data, reducing the data through the process of preparation of abstraction, and grouping the data based on the main issues. Then it proceeds to an interpretative step based on the existing theoretical framework.

\section{Patron-Client (Clientelism) as a Rational Action}

The collapse of the authoritarian, militaristic, and centralistic regime of the New Order in 1998 did not directly make the patron-client political model existing during the regime disappeared. During the New Order Era, the patronage political model seemed more clearly, as the patron was dominated by the government apparatus, military, and Golkar (party) as its political machine. Now, the patron-client political model is more fluid (not single actor/group). In the era of democratic decentralization, patrons can be played by anyone and/or any party, as long as they have access to control the resources. Parties that become clients also vary, depending on the segment and orientation.

James C. Scott (1993), presupposes the model of patronage relationship as the relationship between the two roles. On the one hand, an individual with a higher socio-economic status (as a patron) will utilize his or her influences and resources to provide benefits for the lower socio-economic status of the individuals/groups (clients). On the other hand, the client will repay the benefits received from the patron, by providing support or 
assistance, including personal services. In this context, anyone or group can be a patron as long as they have access to control resources and be able to give benefits to the client. In the era of democratic decentralization, as the parties can act as patron and client is no longer single, the model of patronage relationship is also flexible, fluid, and spread. In fact, the profits that are exchanged depend on the kind of needs that arise and the resources they have.

The flexibility and fluidity of this patronage model are driven by the increasingly varied choice of action (rational choice) as a means of both parties (patrons and client) in maintaining their relationship pattern. In addition, the form of reciprocity (reward) is also changing, depending on the socio-political setting that lies behind it. It is in line with James Coleman's rational choice theory that emphasizes the structure of action with a focus on authority, belief systems, collective action, and norms. Authority is used to control the actions of other individuals who give their rights to others to control the action. Authority becomes an exchange when the right to control the actions of others is exchanged with some services (protection) or financial compensation in an organization (Haryanto 2011).

Changing the pattern and movement orientation of an organization can be regarded as a rational action and similar to what is stated by Patrick Baert (in Wirawan 2013) that this theory can explain social and political behavior by assuming that each individual acts rationally. Because the focus is on individual (actor), he is regarded as an entity that has the purpose (intention) of his action (Ritzer 1992). Although the purpose of an actor is the starting point, there are two things that can confine the action. First is resources; actors with more ownership of resources will easily get their goals than those with none or little ownership. Second, social institutions: negative and positive sanctions 
that emphasize on the needs of certain actions and vice versa (Wirawan 2013).

\section{Islamic Reformist Movement (Garis)}

The emergence of Garis cannot be separated from the role of the leaders of the Islamic Propagation Council (DDI). Some prominent figures of this Islamic organization played an active role and sponsored the emergence of Garis after the fall of Suharto in 1998. As mentioned in the official guidebook of Garis members, on May 14, 1998 a number of Islamic leaders gathered in Jakarta: like Anwar Haryono, Husein Umar, Chep Hermawan, Yusril Ihza Mahendra, K.H. Abdul Qodir Djaelani, Endang Syafe'i (Haji Dapet), K.H. Munawar, and Ahmad Sumargono. Anwar Haryono, Husein Umar, and Ahmad Sumargono are widely known as DDI figures, an organization which was established among others by Muhammad Natsir, former leader of Masyumi Party in the 1950s. In the era of democratic reform, DDI was directly or indirectly considered to be responsible for the birth of a new Islamic political party, the Crescent Star Party (PBB). This party, by most of its activists, is considered a continuation of Masyumi Islamic party and eager to restore the glory of Islamic political party after the fall of the New Order.

One of the goals of Garis' establishment is to save the 1998 reform in favor of Muslims society as this group viewed that the ongoing process of political reform is controlled by the groups that massively promote the ideology of secularism and communism. According to them, these groups of secularism and communism continue to try to influence society, especially the Muslims community. Therefore, Garis was established to protect Muslim society. As a continuation of several meetings of DDI figures, then on July 24, 1999, Garis was officially declared at Pondok Gede, at the Hajj Dormitory, Jakarta, and Chep Hermawan was appointed as its daily leader. 
As an organization which was born from the Da'wah Council, Garis has very strong Islamic nuances, as stated in its vision and mission. The vision of this organization is to fight for the unity of Muslims community, in the framework of the establishment of Islamic sharia (daulah and khiläfah Islämiyyah). While its mission, among others: first, to implement amar ma'rū nahi munkar (enjoining good, forbidding evil). Second, to help the poor's burden and enourage the Muslims. Third, to maintain the purity of the Islamic faith ('aqidab) and eradicate all kinds of heresy and reject the rise of atheism, communism, secularism, pluralism, and liberalism in Indonesia in order to uphold and elevate the word of taubid. Fourth, responding to and criticizing the policies of the government considered zālim (unjust acts) and do not favor the Muslims in Indonesia. Fifth, promoting dakwah (propagation) and jihad for the sake of constituting $k a-$ limatullāh.

Although established and declared in Jakarta, Garis is relatively a local-scale Islamic mass organization. Since 1999, Garis's activities are is more concentrated in Cianjur Regency, West Java. Along with Crescent Star Party (PBB) maneuver in Senayan in 1999 to fight for the establishment of Islamic sharia through re-implementation of the Jakarta Charter, Garis also actively campaigned and mobilized a movement for the establishment of Islamic sharia in West Java. Until now, Garis is considered one of the prominent radical Islamic groups in Cianjur and its surrounding areas. Except being well-known because of its action that often uses violence in sweeping locations considered to be sources of disobedience, prostitution, liquor sales, and drugs, Garis is also known to be the most aggressive organization in rejecting the church construction and sealing the Ahmadiyah community (Hasani and Naipospos 2010). This group received a bit positive response from some of the Islamic groups 
in West Java, especially those that concern to eradicate the proliferating immorality. In a relatively short time, Garis expanded its wings into several places. In addition to Cianjur as its center, Garis branches were also established in Sukabumi, Garut, and Tasikmalaya.

Compared to other religious organizations, the existence of Garis in Cianjur is relatively more advantageous based on several reasons: first, the proximity of the patron of Haji Dapet (Haji Endang Syafe'i), the father of Haji Chep Hermawan, Chief of Garis, to the activists of the Crescent Star Party (PBB) in Jakarta and the Da'wah Council (DDI). Haji Dapet is a successful local businessman in Cianjur. His business is then continued by his son, Chep Hermawan, up to the present. Before being a businessman, Haji Dapet had a career in the military and gave more sympathy to the Darul Islam (DI) movement of Kartosuwirjo in the late 1950s and early 1960s. Along with the failure of Darul Islam rebellion, as a result of his support to DI, Haji Dapet was finally sentenced for 15 years in Nusakambangan prison. (Interview Chep Hermawan, 17/10/2012). It indicates that the role of Hajj Dapet in supporting the implementation of Islamic sharia in Cianjur was associated with the role of DI/NII activists. Although in this research DI/NII linkage with the idea of Islamic sharia establishment in Cianjur is not clearly visible.

Second, strong financial capital owned by Haji Dapet as Garis patron was able to supply all of the financial needs for coordination and regular meetings that involve many groups. While other Islamic organizations in Cianjur generally do not have adequate financial support to make effort and mostly led by a leader of the pesantren.

However, Garis is not only known as an Islamic mass organization that promotes Islamic Sharia, just like the Islamic Defenders Front (FPI), but also as an active political actor. 
After Chep Hermawan failed to be nominated as a candidate for Vice Regent of Wasidi Soetomo in Cianjur, Garis is the only Islamic group that actively criticizes his policy after being elected. In fact, Wasidi Soetomo is also widely known as the Head of Region that strongly supports the implementation of Islamic Sharia in Cianjur during his reign. Although Wasidi Soetomo gained widespread support from the pesantren and the scholars in Cianjur because of his policy which is pro-Islamic sharia, it did not prevent Garis to blaspheme him as regarded not true Muslim. Garis raised the issue of the establishment of illegal churches in Cipanas Region (Carmel church) as an indicator of the local government negligence.

Garis's political consideration whether it supports or not to the struggle of Gerbang Marhamah in Cianjur can also be considered as the act of Garis that choose to withdraw from the Islamic organizations' network that support to the implementation of Islamic Sharia in Cianjur. As stated by Chep Hermawan that he was not able to believe in Wasidi Soetomo after neglecting the construction of the church (Carmel) in Cipanas. In addition, Chep Hermawan also doubted the motives of the Kiai and other Islamic organizations in Cianjur in supporting the Gerbang Marhamah movement but did not take action on the church construction (Interview Chep Hermawan, 17/10/2012).

In fact, the various critics of Garis against Wasidi Soetomo, actually have much to do with the un-accommodated of their political aspirations, i.e. the rejection of Wasidi Soetomo and the ulama as Haji Dapet wanted to propose his son, Chep Hermawan, the Chief of Garis, as the Vice Regent candidate during the Regional Election at that time. This rejection has made Haji Dapet who has much contributed to the funding for the mobilization movement in supporting the implementation of Islamic Sharia in 1999-2000 was heavily offended and this situation has 
made the relationship of Garis with Kiai in Cianjur got worse.

Except actively doing a campaign for the implementation of Islamic Sharia in Cianjur and its surrounding areas, Garis also often takes part in joint actions with various elements of Islamic organizations in Jakarta. For instance, the demonstration to refuse the candidacy of Ahok (Basuki Tjahaja Purnama) as Jakarta's Governor after Jokowi (Joko Widodo) was elected as the President in 2014. In addition, Garis also has several times joined the demonstration movement in support of Palestine, criticizing Israel and USA in Jakarta.

There are no exact data about how many members of Garis in Cianjur and other areas. In several religious events held in Garis' leader house, they were generally attended by hundreds of its members and sympathizers from Cianjur and surrounding areas. During the demonstrations in Cianjur with regard to the rejection of the Carmel church, alcohol raids, and anti-Ahmadiyah movement, it is usually followed by around 100 people. Chep Hermawan usually leads the action by driving his luxurious car, followed by the dozens of motorcycles behind it. (Interview AH, 27/12/2014).

In the mid of 2014, Garis and some of its leaders became widespread concern of Indonesia society. It is related to their support to the radical movement of Islamic State of Iraq and Syria (ISIS), which has established a Caliphate with Abu Bakar al-Baghdadi as its caliph. Garis also sent some of its members to a declaration to support ISIS in Jakarta. Chep Hermawan himself is also not free from controversy when declaring himself as a President of ISIS Indonesia. Because of those actions, while ISIS by the Indonesian government was also regarded as an international terrorist organization, Chep Hermawan and some of Garis leaders were arrested by the police after visiting $\mathrm{Abu}$ Bakar Ba'asyir at Nusakambangan prison in Cilacap. According 
to the police, Chep Hermawan's groups were bringing ISIS's flag and waving it as they came to Cilacap. Garis involvement in the development of ISIS in Indonesia has further strengthened its reputation in the eyes of outsiders as an radical Islamic group movement (DetikNews 2014).

\section{Political Clientelism as Garis' Survival Strategy}

As an Islamic organization which is known to be very vocal and actively performs various actions to fight for the implementation of Islamic Sharia in Cianjur, Garis does not stand alone. Garis has strong patterns of movement and political network with various parties that have access to resources whether in politics, social, economy, and religion.

In the beginning, Garis has a close political relationship with the politicians of the Crescent Star Party (PBB). While religiously it is close to the Da'wah Council and economically gets financial support from family business heritage. But recently it has changed a lot. Garis relationship with the political parties is not only with the Islamic political parties such as PBB, but also with the secular political parties such as Golkar and Gerindra. Hereby, Garis is not only known as an Islamic organization that promotes Islamic Sharia but also as an active political actor. Some of the members of Garis also become board members of certain political parties. Even Chep Hermawan himself was ever registered as PBB official of Cianjur District and also has close relation to Gerindra. During 2014 General Election, politically Garis did not only support single party, but also supported other parties like PAN, Golkar, and Gerindra. (Interview MT, 26/12/2014). Even, Garis then has a close relationship with the Democratic Party and it is caused by a familial relationship between the head of Garis and the officials of Democrat Party of Cianjur (Interview AH, 27/12/2014).

The liquid affiliation of Garis in politics, which is no longer 
associated to Islamic-based political parties, is also recognized by academician from Suryakencana University, Cianjur, as well as observers of the social, political, and religious issues in Cianjur:

"I think that Garis political affiliation is liquid. Although Garis has Islamic ideology, many of the Garis functionaries have political positions in non-Islamic based parties such as in Golkar, PDI-P, PPP, PBB, and Democrats. I do not think Garis has problem in political communication." (Interview DM, 17/12/2014).

Garis's active engagement in politics is supported by the strength of its social capital. Garis' leader has good communication with political parties and also close to other mass organizations in Cianjur, both Islamic such as FPI and secular such as Pemuda Pancasila (PP). Apart from that, Garis gives special attention to the youth especially the student's organization called Rumbis. Although it is indirectly part of Garis, most of its activity is often supported by Garis, especially regarding building use and some other financial needs. (Interview DM, 17/12/2014).

The proximity of Garis with Pemuda Pancasila is not merely a relationship based on interest, but more on familial relationship. The younger sister of Garis leader got married to the son of the head of PP Cianjur. (Interview MT, 26/12/2014). This close relationship also made the conflict that ever happened between PP Cianjur and Garis easier to be solved. Some conflicts happened between them among others are Ariel Peterpan case in Bandung in which PP supported Ariel Peterpan while Garis was in opposite position, the conflict in Cipanas, as well as several other cases unrelated to religious issues in Cianjur (Interview SS, 26/12/2014).

Meanwhile, Garis relationship with other radical Islamic organizations such as FPI, Gibas, and so forth, are due to the historical fact and financial support. Most of them (FPI and the 
other similar organizations) were originally part of or have been members of Garis in promoting the issue of Islamic Sharia implementation in Cianjur. But lately, without definite reason, their relationship is no longer harmonious. Some of them got separated and then established new organizations, including FPI, Gempar, and the similar. (Interview ASH, 25/12/2014). Nevertheless, all organizations that previously have been part of Garis yet they have become independent organizations, still continue to establish communication and coordination with Garis, especially in term of conducting sweeping and raid actions (Interview of $U A$, 16/11/2014).

At a glance, it is apparent that Garis relationship with other radical Islamic organizations in Cianjur has a problem. Their strength that used to be one has already split into various forms. But it does not prevent their coordination and communication relationship, especially in undertaking a costly action. This is allegedly due to the strong financial capital owned by Garis. Compared to the other mass organizations established after the Reformation Era in 1998, Garis is economically well-established. The Head of Garis has various businesses that can be used as financial support in every movement; starting from the ownership of plastic processing business, market, stalls, sand-digs, up to residential property business. That is why Garis financially has no problem and does not rely on the government for financial support. Even, some of the Islamic organizations that have similar idea to promote Islamic Sharia implementation in Cianjur mostly request for financial assistance to Garis (Interview of $U A, 16 / 11 / 2014)$.

The 'split' that occurred between Garis with other mass organizations in Cianjur, according to ASH (interview, 25/12/2014) was caused by its political interests. According to him, the act of Garis that criticized Gerbang Marhamah regulation is only a 
reaction to its disappointment on the rejection of the nomination of Chep Hermawan as a candidate of vice regent of Wasidi Soetomo in the local election (Pilkada) of Cianjur. Similarly, the act of Garis in declaring its willingness to provide a place of burial for the Bali Bombers and the declaration of Chep Hermawan as the president of ISIS Indonesia, are also considered its strategy in utilizing the momentum to be well acknowledged by the public.

Even in the case of assaulting and sealing the mosque of Jemaat Ahmadiyah Indonesia (JAI) in Cianjur, according to one of Ahmadiyah figures in Cianjur, AH (interview, 27/12/2014) is merely an attempt to show its existence and to increase the prestige of Garis to be better known nationally. Therefore, the JAI considers that the actions taken by Garis are not for religious reasons. Those who become the members of Garis do not have adequate religious understanding. Considering that, Garis never attended scientific discussion held by JAI Cianjur which aims to discuss their disagreement with JAI existence in Cianjur. Once, there was a representative who claimed to be a representative of Garis. But after being confirmed to the related person, he was a representative of Jamaah Tabligh Cianjur.

'Utilizing' religious issues as the alibi in various activities of Garis movement were proven lately. Garis is allegedly involved in many 'backing' for parties that have problems with the leasing of motor vehicles. People in Cianjur who have problems with motor vehicle loan payments and being chased by debt-collectors were looking for protection to Garis. Therefore, there has been a physical clash between Garis and the debt collectors who want to take back the motor vehicles which credits are considered problematic (Budiyanto 2012; Poskotanews 2012). So, it is not surprising that in front of the headquarter as well as the head of Garis' house in Cianjur, there is a big banner expressing 
invitation to the people of Cianjur regency to fight for the debt collectors. Since then, their existence is considered trouble maker. It is also acknowledged by MT, the politician of PBB Cianjur (Interview, MT 26/12/2014).

The use of religious issues as the alibi or shield of Garis' movements is also recognized by a politician of Gerindra, as well as caretaker of PP Cianjur. According to him, any movement of Islamic-based mass organizations in Cianjur, including Garis, often use religion as a mask to gain their profit. (Interview SS: 26/12/2014). For them, the most important thing is respecting each other, keeping safe, and not interfering their respective zone. So there is no clash as every mass organization in Cianjur already has its own territory and work area respectively:

"... each has its own territory. Garis has its own territory. Dishub (government's department of transportation) has a car parking. Pemuda Pancasila takes control of discotheque. So, each is not supposed to disturb other domain. What makes a problem is because of the disturbing of others. So actually we know which Garis' domain, PP's domain, and GIBAS' domain. Each is not allowed to get into other domain because it would disturb others. Before I took control of this discotheque, it was often raided. But now it was not, as everyone has already known it" (Interview SS: 26/12/2014).

In addition, Garis also has established a pesantren as a shield and supporters for its movement. One of the leaders of a pesantren in Cianjur in the beginning sympathized with the Garis movement that actively promotes the implementation of Islamic Sharia in Cianjur. But later after having known that Garis has conducted a lot of provocative activities by bringing the name of pesantren, then many pesantrens withdrew their support. Pesantrens feel much 'abused' by Garis movement that always brings religion as its excuse. For example, during the demonstration and sweeping action, Garis often invites Santri with 
the ground to attend religious activities. The students usually will be picked up and guarded by car for free. (Interview SU: 27/12/2014). Since then, Garis relationship with the pesantren began to crack.

Despite the relation of Garis with some other mass organizations (both religious and secular), Kiai, pesantren, and some politicians in Cianjur begun to crack, but its existence remains sturdy, even its movement is predicted to continue and grow. Garis is a religious organization that has many strong economic resources compared to other organizations in Cianjur. Except promoting the issue of Islamic Sharia implementation as its capital to attract religious sympathy in the region of Cianjur, Garis also has become a magnet of economy so that it easily recruit its members. (Interview DM: 17/12/2014). Since the leader of Garis has the largest plastic processing company in Cianjur, Garis is able to attract a lot of manpower. From this factory also, he opened a business relationship with Jakarta, as a supplier of finished and semi-finished materials from the processed plastic. In fact, in several demonstration activities, Garis also involved its employees as demonstrators. (Interview DM: 17/12/2014).

\section{Changing the Movement Orientation}

In the early period of its emergence, the orientation of Garis movement was dominated by ideological motives, with the main issue of Islamization or Islamic Sharia implementation. But in the next stage of its development, its orientation has shifted from ideological motives to economy. Yet, its ideological motive is not completely vanished but already mixed with economic motives. In other word, pragmatism-of economy-has now become its new ideology that underlies the change of its orientation and motive movement. Religious motive is used as justifications for its economic and political interests.

The politics of clientelism practiced by Garis that involved 
a number of other radical Islamic groups or organizations both Islamic and secular as well as politicians or political parties in the local area of Cianjur eventually led to premanism action. Thus, it can be said that democratization at the local level grows and develops in line with the strengthening of groups or organizations of premanism. Religious characteristic and identity were successfully played by Garis, for the purpose of its existence and movement in Cianjur.

The change of orientation, motive, and affiliation of Garis movement, in this case, from supporting Islamic Sharia implementation to the mastery of political and economic resources, such as assigning its members as representatives of the regional people, attempting to control local but failed, controlling the parking lot, market security, and other 'illegal' businesses are rational choices in order to survive.

The flexibility and fluidity of this patronage model, which then influence to its orientation and movement are driven by the increasingly varied choices of action (rational choice) as the means of both sides (patrons and client) in maintaining their relationship pattern. In addition, the kind of reward is also changing, depending on the socio-political setting that lies behind it. It is in line with James Coleman's rational choice theory, that the authority is used to control the actions of other individuals who give their rights to others to control the action (Haryanto 2011). Since the authority becomes an exchange, when the right to control the actions of others is exchanged with some services (protection) or financial compensation in an organization in order to be able to exist and survive, Garis took an action to shift its affiliation movement. Islamic political parties, Islamic politicians, as well as Islamic organizations are no longer its dominance affiliation. Even in some cases, the affiliation built by Garis does not always make its goals successfully achieved. 
Based on analysis, the change of motives and orientation of Garis did not suddenly occur. There are some factors, among others.

First, fighting for economic resources. The will to control economic resources becomes dominant factor affecting to the existence and orientation change of Garis movement in Cianjur and its surrounding areas from Islamism to premanism. Formerly, Garis actively promoted the issue of Islamic Sharia implementation, later it much involved in backing for those who have problems with leasing (debt-collector). Even the issue which is arising up still using religious identity and for the purposes of defending the interests of society, it turns behind the guise that there is a financial benefit gained by Garis. For example, the effort to take back motor vehicles which credits are considered problematic, there is a considerable cost of withdrawal. Approximately, the fee is about 10 Million Rupiah for two-wheeled motor vehicles and more than 10 Million Rupiah for four-wheeled motor vehicles. This withdrawal fee is allegedly the motive of Garis in protecting the troubled party earlier. If the leasing party is willing to recover the vehicle with the credit problem, then it should pay the fee. (Interview AH, 27/12/2014).

In addition, Garis also becomes a safeguard for some 'illegal sand digging' in Cikalong, Cianjur (Interview AH, 27/12/2014). There are some sand digging areas that belong to Garis' leader family. So it is not surprising if the orientation of Garis movement has changed. They just use religion as a 'shield' for their economy-oriented action. In fact, Garis also has an economically viable 'land clearing' area, as 'land plots' are also owned by other mass organization. (Interview SS: 26/12/2014).

This situation forced Garis to change its movement orientation to maintain its power and followers. If resource is not occupied by Garis, while other similar organization takes it, they 
might lose their authority to control the new potential economic resources in Cianjur Regency. In fact, some of the similar organizations in Cianjur, like FPI and Gibas that are formerly part of Garis' members then got separated and tried to occupy it. Although both of them also have their own 'area'.

Second, weak bureaucracy and law enforcement. Another factor that contributes to the orientation change of Garis movement in Cianjur and its surrounding areas is weak bureaucracy and law enforcement from the government apparatus. The high threat felt by the political elites or society, in general, made Garis and other similar mass organizations in Cianjur have an alternative choice (rational choice) to become a kind of 'protector' for certain interests. This condition allows them to negotiate for the benefit of a particular person or group.

In Cianjur Regency, there are many bureaucratic affairs that are considered too complicated. Some parties then request that any process is supposed to be faster. In the case of business license for example, because the businessmen do not want to get disturbed then they mostly choose to give bribe for the purpose of quick service. As a result, many emerging businesses are illegal, or contrary to the vision of Cianjur Regency itself such as sand mining, and night entertainment. (Interview AH, 27/12/2014). Even though mass organization such as Garis often conducts sweeping and raiding, their businesses still keep running as they thought to have paid some money for guarantee, not the official state's tax. Besides, they also have got backing for their businesses.

In fact, the government and the security apparatus actually know the existence and actions of all organizations in Cianjur Regency. But, as their existence is politically considered profitable, especially in terms of mass mobilization to give support during General and Local Elections, then they got a chance to 
exist and develop. Therefore, both mass organizations and government officials in Cianjur Regency have already known their own domain (Interview SS, 26/12/2014).

These conditions then influence the existence, sustainability, and movement orientation of the radical Islamic group, like Garis, in Cianjur Regency. Apart from that the weak of the state apparatus will also open contestation opportunities for the people to fight for the access of resources. Moreover, if the resource would give profits economically, the contestation among mass organizations, between mass organization and the community, and between mass organization and government possibly happens. The party that wins the contestation will certainly use all of the resources, including using religious issues, as practiced by Garis.

\section{Conclusion}

In general, it can be said that the existence, development, and orientation of radical Islamic group movement in the era of democratic decentralization in Cianjur, West Java are quite unique. James C. Scott (1993) states that patronage model is preserved and sustains their existence although its nature and form are more fluid. Patrons provide life guarantees (security or economy) by providing access to resources, while clients act as the guardians of politics, economy, and mass mobilization support. Such patronage relationship is a rational choice for both parties to be able to survive and develop along with the dynamics of social and political development.

The patronage relationship did not occur formally organizational but rather informal. In addition, if the political affiliation of radical religious organizations before and in the early period of Reformation Era was more dominated by Islamic political parties, especially political parties that actively promoted 
the implementation of Islamic sharia, in this era of democratic decentralization their political affiliation is liquid. This condition happened because of the political reality that the politicians mostly prefer to save their own businesses, votes, or constituents rather than party's ideology. The society also needs backing in case of having problems while the state's apparatus seemed to be slow in giving responses.

If before and during the early period of reform, the orientation of the radical religious group movements was more dominated by ideological motive that is the implementation of Islamic sharia, then in the era of democratic decentralization their orientation has shifted to economic pragmatism. Their ideological motive does not completely disappear but already mixed or just used as a wrap or mask for economic motives. In other words, pragmatism has become new ideology that underlies the change of their orientation and movement motives.

The development of political clientelism model involving a number of radical religious organizations with local politicians to some extent endangers the behavior of premanism and corruption at the local level. In fact, democratization at the local level grows and develops with the growth of premanism organizations, similar to the practices of bossism in Philippine and Thailand (Sidel 1996). This condition also happened in Cianjur, West Java due to the interest of controlling economic resources so that all the parties consider necessary to maintain the areas that become the sources of their economy. So what happens is every party controls the area that is claimed to be their territory. The weak bureaucracy and law enforcement are the indication that the state's apparatuses are absent in solving various bureaucratic and security problem. And public order issues become a kind of justification for the emergence and development of radical religious organizations in the local level. The state seems too 
POLITICAL CLIENTELISM AS THE WAY OF SURVIVAL ...

busy with the issue of the day to day politics. The issue of life demands and community services has become less of a concern.

\section{Acknowledgement}

This article is the development of research that is conducted by the author and M. Zaki Mubarak in 2014. The research result in Solo has been published in 2016, entitled: "Dari Islamisme ke "Premanisme": Pergeseran Orientasi Gerakan Kelompok Islam Radikal di Era Desentralisasi Demokrasi". Thank you for the reviewers and anyone who makes this publication possible.

\section{Bibliography}

Budiyanto. 2012. "Ketua Garis Minta Leasing Tak Pakai Debt Collector." Inilah.Com. https://m.inilah.com/news/detail/1905225/ketua-garis-minta-leasing-tak-pakai-debtcollector.

Buehler, Michael, and Dani Muhtada. 2016. "Democratization and the Diffusion of Sharia Law : Comparative Insights from Indonesia." South East Asia Research 24 (2): 261-82. doi:10.1177/0967828X16649311.

DetikNews. 2014. "Profil Chep Hermawan, 'Presiden' ISIS Indonesia Yang Ditangkap Polisi.” News.Detik.Com. https:// news.detik.com/berita/2660690/ini-profil-chep-hermawan-presiden-isis-indonesia-yang-ditangkap-polisi.

Haliq, Fathol. 2014. "Perilaku Politik Kelas Menengah Madura." Karsa 22 (2): 211-22.

Haryanto, Sindung. 2011. Sosiologi Ekonomi. Yogyakarta: Ar-Ruzz Media.

Hasani, Ismail, and Bonar Tigor Naipospos. 2010. Radikalisme Agama Di Jabodetabek Dan Jawa Barat: Implikasinya Terhadap Jaminan Kebebasan Beragama/Berkeyakinan. Jakarta: Pustaka Masyarakat Setara. 
Human Right Watch. 2013. Atas Nama Agama: Pelanggaran Terhadap Minoritas Agama Di Indonesia. Jakarta: Human Right Watch.

Iqbal, Mahathir Muhammad. 2014. "Dinamika Wacana Formalisasi Syariat Dalam Politik: Ikhtiar Menemukan Relevansi Relasi Agama Dan Negara Perspektif Indonesia." Walisongo: Jurnal Penelitian Sosial Keagamaan 22 (1): 83-104.

Jati, Wasisto Raharjo. 2013. "Radicalism in the Perspective of Islamic-Populism: Trajectory of Political Islam in Indonesia." Indonesian Institute of Sciences 07 (02): 268-87.

Jumadi, and Mohammad Rizal Yakoop. 2014. "Etnisitas Sebagai Instrumen Politik Dan Keamanan Di Kalimantan Barat Pasca Rezim Orde Baru.” Jurnal Ilmu Sosial Dan Ilmu Politik 17 (1): 17-34.

Kafid, Nur. 2016. “Dari Islamisme Ke 'Premanisme': Pergeseran Orientasi Gerakan Kelompok Islam Radikal Di Era Desentralisasi Demokrasi." Masyarakat: Jurnal Sosiologi 21 (80).

Mubarak, M Zaki. 2015. "Dari NII Ke ISIS Transformasi Ideologi Dan Gerakan Dalam Islam Radikal Di Indonesia Kontemporer." Epsiteme 10 (1): 78-98.

Mudhoffir, Abdil Mughis. 2015. "Political Islam and Religious Violence in Post-New Order Indonesia." Masyarakat: Jurnal Sosiologi 20 (1): 1-22.

Nurcholish, Ahmad. 2011.10 Tahun ICRP: Melawan Kekerasan Atas Nama Agama. Jakarta: ICRP.

Poskotanews. 2012. "Kantor Leasing Dirusak Massa Di Sukabumi." Poskotanews.Com. http://poskotanews. com/2012/09/14/kantor-leasing-dirusak-massa-di-sukabu$\mathrm{mi} /$.

Ritzer, George. 1992. Contemporary Sociological Theory. New York: McGraw-Hill. 
POLITICAL CLIENTELISM AS THE WAY OF SURVIVAL ...

Rizky, Ahmad, and Mardhatillah Umar. 2010. "Melacak Akar Radikalisme Islam Di Indonesia.” Jurnal Ilmu Sosial Dan Ilmu Politik 14 (November): 169-86.

Scott, James C. 1993. Perlawanan Kaum Tani. Jakarta: Yayasan Obor.

Sidel, John T. 1996. "Siam and Its Twin? Democratization and Bossism in Contemporary Thailand and the Pihilippines." IDS Bulletin 27 (2): 57.

Suputra, Pande Made, I Nengah Bawa Atmadja, I Gede Parimartha, and I Wayan Ardika. 2011. "Political Coercion in the Reformation Era in Buleleng Regency." E-Journal of Cultural Studies 5 (2): 1-8.

Tempo. 2010. “Tempo Edisi Khusus: Kartosoewirjo Mimpi Negara Islam.” Majalah Tempo, August.

Wirawan, Ida Bagus. 2013. Teori-Teori Sosial Dalam Tiga Paradigma: Fakta Sosial, Definisi Sosial, Dan Perilaku Sosial. Jakarta: Kencana. 
This page intentionally left blank 